\title{
Trial Summary Sequence Number
}

National Cancer Institute

\section{Source}

National Cancer Institute. Trial Summary Sequence Number. NCI Thesaurus. Code C83446.

An identifier that describes the relative position of trial summary data within a series. 